\title{
Effect of feeding chayote (Sechium edule) meal on growth performance and nutrient utilization in indigenous pig (Zovawk) of Mizoram
}

\author{
James Lalthansanga and A. K. Samanta \\ Department of Animal Nutrition, College of Veterinary Sciences and Animal Husbandry, Central Agricultural \\ University, Selesih, Aizawl - 796 001, Mizoram, India \\ Corresponding author: A. K. Samanta, e-mail: aksamanta73@gmail.com, JL: jamesltsanga@gmail.com \\ Received: 19-02-2015, Revised: 19-06-2015, Accepted: 28-06-2015, Published online: 26-07-2015
}

doi: 10.14202/vetworld.2015.918-923 How to cite this article: Lalthansanga J, Samanta AK (2015) Effect of feeding chayote (Sechium edule) meal on growth performance and nutrient utilization in indigenous pig (Zovawk) of Mizoram, Veterinary World 8(7); 918-923.

\begin{abstract}
Aim: This study was planned to investigate the effect of feeding different levels of chayote (Sechium edule) meal by replacing standard concentrate mixture (CM) on the growth parameters such as feed intake, body weight gain, average daily gain (ADG) and feed conversion ratio (FCR), and nutrient utilization in indigenous pig of Mizoram.

Materials and Methods: Twenty-four growing indigenous pigs (Zovawk) were used to study the effect of feeding chayote (Sechium edule) meal (fruits and leaves at the ratio 4:1) on growth performance and nutrient utilization. They were allocated randomly into 4 treatment groups $\left(\mathrm{G}_{1}, \mathrm{G}_{2}, \mathrm{G}_{3}\right.$ and $\left.\mathrm{G}_{4}\right)$. Chayote meal was used to replace standard $\mathrm{CM}$ (pig grower ration) at $0 \%\left(\mathrm{G}_{1}\right), 20 \%\left(\mathrm{G}_{2}\right), 30 \%\left(\mathrm{G}_{3}\right)$, and $40 \%\left(\mathrm{G}_{4}\right)$.

Results: During the feeding trial of 90 days, it was found that the dry matter (DM) intake decreased as the level of chayote meal increased. For $\mathrm{G}_{1}, \mathrm{G}_{2}, \mathrm{G}_{3}$, and $\mathrm{G}_{4}$, the $\mathrm{ADG}(\mathrm{kg})$ was $0.24 \pm 0.04,0.23 \pm 0.03,0.18 \pm 0.02$, and $0.18 \pm 0.02$, respectively, and the feed conversion efficiency was $5.42 \pm 0.44,4.93 \pm 0.17,5.38 \pm 0.05$, and $5.74 \pm 0.53$, respectively. However, there was no significant difference $(\mathrm{p}>0.05)$ among the different treatment groups in respect to ADG and FCR. At the end of the feeding trial, digestibility trial was conducted to study the effect of feeding chayote meal in the digestibility of the different nutrients by the experimental animals. From the digestibility trial, it was revealed that the digestibility coefficient of DM, crude protein, and crude fiber were also similar ( $p>0.05$ ), although the ether extract digestibility in $G_{1}$ was significantly low ( $p<0.01$ ) as compared to $\mathrm{G}_{2}, \mathrm{G}_{3}$, and $\mathrm{G}_{4}$.
\end{abstract}

Conclusion: Chayote meal could safely replace the standard grower ration up to $40 \%$ in the diet of growing local pigs without causing any adverse effects on growth and nutrient utilization.

Keywords: chayote, indigenous pigs, growth performance, nutrient digestibility.

\section{Introduction}

Mizoram, one of the states of the North-Eastern hilly region of India is situated between the $20.58^{\circ}$ and $23.35^{\circ}$ north latitude and $92.15^{\circ}$ and $93.29^{\circ}$ east longitude. Agriculture has been one of the main occupations in Mizoram in which animal husbandry occupies a potential source of rural economy. Among the livestock species, pig is by far the most populous and popular livestock in Mizoram and shows the highest percentage of growth in its population.

Feed cost accounts to $70-85 \%$ of total recurring expenditure [1] and therefore an important aspect in pig husbandry is to minimize the cost of feeding by the utilization of unconventional feedstuffs such as sweet potato, chayote, tapioca, etc. which are available locally. The expenditure of feeding pigs with unconventional feed varies considerably with productive traits of the pig and marketing potential of locally available feedstuffs [2].

Chayote or Squash, locally called "Iskut" in Mizoram has been cultivated extensively and utilized

Copyright: The authors. This article is an open access article licensed under the terms of the Creative Commons Attributin License (http:// creative commons.org/licenses/by/2.0) which permits unrestricted use, distribution and reproduction in any medium, provided the work is properly cited. for human consumption as well as pig feed. The state probably has the largest area under squash cultivation in India, though it is also grown in other states of the North East. The area under cultivation of chayote in Mizoram has recorded steady increase with a production of 24,455 million tons in 2006-2007 [3]. During the peak season, plenty of squash fruits are available in the market, the price of which even goes down to Rs. 2 per kilogram [4]. The chayote plant yields shoots which are used as vegetable greens, vines as an ornament for fences or as animal fodder, and edible subterranean storage roots [5].

Scientific information on the use of chayote fruits and leaves in pig ration are not available. Keeping in view the above mentioned facts, the research was carried out with the objective of studying the growth and nutrient utilization of Zovawk pigs fed on different levels of chayote (Sechium edule) meal (fruits and leaves) in the diet.

\section{Materials and Methods}

\section{Ethical approval}

The research was carried out as per the guidelines in force at the time of carrying out the experiment and approval of Institutional Animal Ethics Committee. 


\section{Experimental animals and design}

The experimental animals used were an indigenous breed of pigs found in Mizoram, locally called Zovawk. Zovawk is small type local pigs. Males are bigger than females and can attain full growth in 3 years and weigh as much as $60-70 \mathrm{~kg}$, while the females may be as much as $50-55 \mathrm{~kg}$ in live weight. The body is stout with a short neck. The abdomen is large and can sometimes touch the ground, while standing which conform an arch back. The rump region is smooth and the tail is a long bearing switch with long hairs. 24 indigenous breed of pigs of average body weights were allocated randomly into 4 treatment groups $\left(G_{1}, G_{2}, G_{3}\right.$, and $\left.G_{4}\right)$ and housed in the well-ventilated animal shed. A provision for feeding individually twice a day was arranged. Fresh drinking water was provided at all times. The duration of the feeding trial was 90 days.

\section{Dietary treatment}

A Grower-Finisher ration was prepared [6]. This mixture was considered as a Standard Concentrate mixture $(\mathrm{CM})$. The ingredient composition of the standard $\mathrm{CM}$ was yellow maize $55 \%$, wheat bran $20 \%$, groundnut cake $16 \%$, fish meal $7 \%$, mineral mixture $1.5 \%$, and common salt $0.5 \%$. Three types of rations that are iso-nitrogenous to the standard $\mathrm{CM}_{\mathrm{S}}$ were prepared for feeding to the three different groups $\left(\mathrm{G}_{2}, \mathrm{G}_{3}\right.$, and $\left.\mathrm{G}_{4}\right)$ of animals. Chayote meal was used to replace standard CM (pig grower ration) at $0 \%\left(\mathrm{G}_{1}\right)$, $20 \%\left(\mathrm{G}_{2}\right), 30 \%\left(\mathrm{G}_{3}\right)$, and $40 \%\left(\mathrm{G}_{4}\right)$. The chayote meal consisted of the fruits and leaves of $S$. edule mixed in the ratio of $4: 1$. This total mixture was cooked for $30 \mathrm{~min}$ before feeding to the animals.

\section{Experimental procedure}

After a provision of environmental and dietary adaptation period of 10 days, a 90-day feeding trial was conducted. During this period, the daily dry matter (DM) intake was recorded. The body weight of the animals was recorded before the start of the feeding trial and at 7 days interval during the experimental period. A digestion trial of 5 days was conducted by taking 3 animals from each group. Feeds offered and residues left were recorded daily during the digestion trial. Feces voided daily by the individual animal were weighed separately in previously weighed containers. The amount of feces collected at $24 \mathrm{~h}$ was quantified and representative samples were taken daily for aliquoting in the laboratory. Representative samples of each of the concentrate feed ingredients, chayote fruits, leaves, and meal used in the experiment, residual feeds, and fecal matter were analyzed in the laboratory for proximate principles as per the method described by AOAC [7], Fiber fractions as per the method described by Goering and Soest [8] and calcium as per the method described by Talapatra et al. [9].

\section{Statistical analysis}

All the data were analyzed statistically using Statistical Packages for Social Sciences Software,
Version 17.00 (SPSS Inc., Chicago, USA), and by the statistical method [10] for discussion and interpretation of results.

\section{Results and Discussion}

\section{Chemical composition}

Nutrient composition of chayote fruits, stems, leaves, and meal is presented in Table-1. It was observed that the DM (\%) of boiled chayote meal, chayote fruit, chayote leaf, and chayote stem was $15.10,5.92,17.50$, and 18.32 , respectively. The chayote fruit contains less DM percentage (5.92) as compared to leaves and stem. Further, on DM basis, the chemical composition of cooked chayote meal, chayote fruit, chayote leaf, and chayote stem were $5.87,5.97,16.14$, and $14.99 \%$, respectively for total ash; $13.62 \%, 14.88 \%, 15.01 \%$, and $14.58 \%$, respectively for crude protein $(\mathrm{CP}) ; 0.70 \%, 0.83 \%, 1.15 \%$, and $1.10 \%$, respectively, for ether extract (EE); $11.73 \%, 7.53 \%, 12.10 \%$, and $21.71 \%$, respectively, for crude fiber (CF); and $55.53 \%, 70.79 \%, 55.60 \%$, and $47.62 \%$, respectively, for nitrogen-free extract (NFE). These observations were in agreement with Yoshimura [11] who reported that the chayote fruit contains $4.03 \% \mathrm{DM}$, and the DM contained $16.26 \%$ CP, $1.17 \%$ EE, $7.31 \%$ CF, $68.39 \%$ NFE, and $6.86 \%$ total ash, respectively. Similar observations were also observed by Nagarajaiah and Prakash [12] in S. edule dehydrated peels in which $100 \mathrm{~g}$ contained $15.15 \mathrm{~g}$ proteins, $45.24 \mathrm{~g}$ insoluble fiber, and $2.32 \mathrm{~g} \mathrm{EE}$.

The ration for different experimental groups consisted of different levels of CM ingredients and chayote meal. The chemical composition of different experimental feed is presented in the Table- 2 . On laboratory analysis, the DM of diets offered to $\mathrm{G}_{1}, \mathrm{G}_{2}, \mathrm{G}_{3}$, and $\mathrm{G}_{4}$ was $86.63 \%, 86.35 \%, 87.21 \%$, and $85.74 \%$, respectively. The chemical composition of diets for $G_{1}, G_{2}, G_{3}$, and $G_{4}$ were $8.36 \%, 10.38 \%$, $9.63 \%$, and $9.56 \%$, respectively, for total ash; $18.05 \%$, $17.90 \%, 17.90 \%$, and $18.14 \%$, respectively, for $\mathrm{CP}$;

Table-1: Nutrient composition of chayote (S. edule) fruit, stem, leaves, and meal.

\begin{tabular}{lcccc}
\hline Parameters & $\begin{array}{c}\text { Chayote } \\
\text { meal }\end{array}$ & $\begin{array}{c}\text { Chayote } \\
\text { fruit }\end{array}$ & $\begin{array}{c}\text { Chayote } \\
\text { leaf }\end{array}$ & $\begin{array}{c}\text { Chayote } \\
\text { stem }\end{array}$ \\
\hline DM \% & 15.10 & 5.92 & 17.50 & 18.32 \\
Total ash \% & 5.87 & 5.97 & 16.14 & 14.99 \\
CP \% & 13.62 & 14.88 & 15.01 & 14.58 \\
EE \% & 0.70 & 0.83 & 1.15 & 1.10 \\
Crude Fiber \% & 11.73 & 7.53 & 12.10 & 21.71 \\
NFE \% & 55.53 & 70.79 & 55.6 & 47.62 \\
Acid insoluble & 0.02 & 0.01 & 0.05 & 0.03 \\
ash \% & & & & \\
Neutral detergent & 38.02 & 29.34 & 33.86 & 41.67 \\
fiber \% & & & & \\
Acid detergent & 24.92 & 19.67 & 37.77 & 39.23 \\
fiber \% & & & & \\
Calcium \% & 0.15 & 0.25 & 0.67 & 0.46 \\
Phosphorus \% & 0.93 & 0.60 & 0.82 & 1.57 \\
\hline
\end{tabular}

$\mathrm{DM}=$ Dry matter, $\mathrm{NFE}=$ Nitrogen free extract,

$\mathrm{CF}=$ Crude fiber, $\mathrm{EE}=$ Ether Extract, $\mathrm{CP}=$ Crude protein, S. edule $=$ Sechium edule 
Table-2: Nutrient composition of experimental feed fed to different experimental groups.

\begin{tabular}{|c|c|c|c|c|}
\hline \multirow[t]{2}{*}{ Parameters } & $\mathbf{G}_{1}$ & $\mathbf{G}_{\mathbf{2}}$ & $\mathbf{G}_{3}$ & $\mathbf{G}_{4}$ \\
\hline & $\begin{array}{l}\text { Concentrate } \\
\text { mixture }\end{array}$ & $20 \%$ & $30 \%$ & $40 \%$ \\
\hline DM \% & 86.63 & 86.35 & 87.21 & 85.74 \\
\hline Total Ash \% & 8.36 & 10.38 & 9.63 & 9.56 \\
\hline $\mathrm{CP} \%$ & 18.05 & 17.90 & 17.90 & 18.14 \\
\hline EE \% & 0.67 & 1.74 & 1.77 & 1.92 \\
\hline CF \% & 5.02 & 6.51 & 7.20 & 7.41 \\
\hline NFE \% & 67.9 & 64.9 & 63.5 & 62.97 \\
\hline Acid insoluble ash \% & 0.05 & 0.09 & 0.08 & 0.07 \\
\hline $\begin{array}{l}\text { Neutral detergent } \\
\text { fiber } \%\end{array}$ & 34.76 & 32.35 & 32.98 & 33.54 \\
\hline Acid detergent fiber $\%$ & 10.32 & 13.95 & 17.35 & 19.51 \\
\hline Calcium \% & 0.27 & 0.27 & 0.28 & 0.24 \\
\hline Phosphorus \% & 1.01 & 0.79 & 0.82 & 0.84 \\
\hline
\end{tabular}

$\mathrm{DM}=$ Dry matter, NFE $=$ Nitrogen free extract, $\mathrm{CF}=\mathrm{Crude}$ fiber, $\mathrm{EE}=$ Ether Extract, $\mathrm{CP}=$ Crude protein

$0.67 \%, 1.74 \%, 1.77 \%$, and $1.92 \%$, respectively, for EE; $5.02 \%, 5.08 \%, 7.20 \%$, and $7.41 \%$, respectively, for $\mathrm{CF}$; and $67.90 \%, 64.90 \%, 63.50 \%$, and $62.97 \%$, respectively, for NFE.

\section{Feed intake}

From the perusal of the Table-3, it is observed that the average DM intake ( $\mathrm{g} /$ head/day) was $1263.27 \pm 212.18, \quad 1115.97 \pm 153.87, \quad 970.71 \pm 144.35$, and $1055.69 \pm 113.83$ for $G_{1}, G_{2}, G_{3}$, and $G_{4}$, respectively. The DM that the feed intake ( $\mathrm{kg} / \mathrm{pig} /$ day) was $1.33,1.45,1.36$, and 1.25 , respectively, for $0 \%, 5 \%$, $10 \%$, and $15 \%$ supplementation of cottonseed cake in the standard concentrate diet [13]. However, statistical analysis of the data revealed that the DM intake of feed by pigs of different groups did not differ significantly $(\mathrm{p}>0.05)$. The numerical reduction of DM intake in experimental groups may be attributed to more voluminous nature of the cooked chayote meal. The high moisture content of the experimental feed rendered it quite voluminous during feeding, which might have triggered the satiety center of the brain before the actual DM requirement of the animal was met [14], on incorporating ajar seed kernel in the diet of crossbred pigs, also observed the feed intake was $1.7 \mathrm{~kg}$ /day. Slight variations with the present observation may be due to breed differences as the animals used in the present study were small, non-descriptive type of pigs.

\section{Growth performance}

The body weight changes of the experimental pigs during the 14 weeks of experimental period has been depicted in Figure-1, and the performance of the local pigs fed on chayote meal as replacement of standard CM is presented in Table-4. It was observed that the average body weight gain was highest $(21.22 \pm$ $3.73 \mathrm{~kg}$ ) in $\mathrm{G}_{1}$ and lowest in $\mathrm{G}_{3}(16.43 \pm 2.42 \mathrm{~kg}$ ) for the experimental period of 90 days. The values for feed conversion ratio (FCR) observed during the experiment were $5.42 \pm 0.44,4.93 \pm 0.17,5.38 \pm 0.05$,

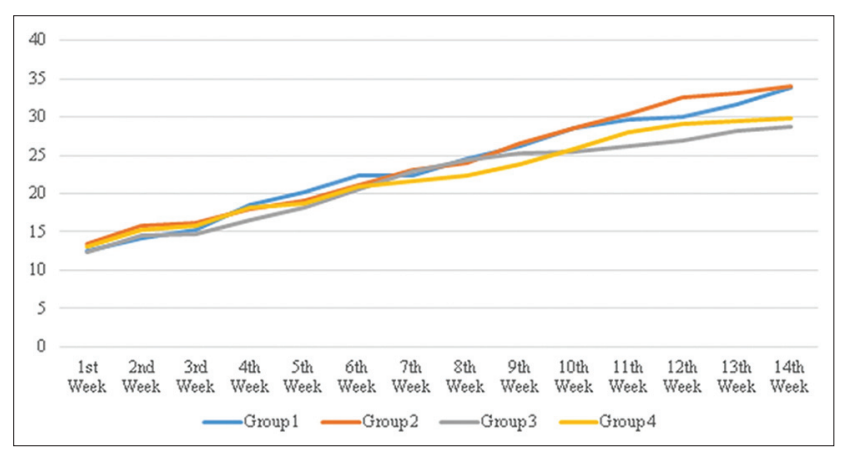

Figure-1: Weekly body weight changes $(\mathrm{kg})$ of different treatment groups.

and $5.74 \pm 0.53$ for $G_{1}, G_{2}, G_{3}$, and $G_{4}$, respectively. This was in agreement with Keoboualapheth and Mikled [15], who reported that $10 \%, 20 \%$, and $30 \%$ of the rice bran replacement by Stylosanthes guianensis CIAT 184 foliage resulted in similar FCR. The close similarity may be attributed to the possibility of breed resemblance as an indigenous pig breed of Thailand was used in their study. Comparatively poor FCR was observed with the increasing replacement of $\mathrm{CM}$ with unconventional feedstuffs. In the present study, there was an increasing tendency of feed conversion efficiency values when higher amount of chayote meal was fed. This tendency was also observed by Halimani et al. [16] who fed Acacia leaf meals on growing Large White pigs. Pigs fed diets including leaf meals have been shown to have low nitrogen retention, which could explain the decline in weight gain [17]. The average daily gain (ADG) $(\mathrm{kg})$ of the experimental animals in the present study was $0.24 \pm 0.04,0.23 \pm 0.03,0.18 \pm 0.02$, and $0.18 \pm 0.02$ for $\mathrm{G}_{1}, \mathrm{G}_{2}, \mathrm{G}_{3}$, and $\mathrm{G}_{4}$, respectively. Kumaresan et al. [18] observed that the ADG of nondescript local pigs of Mizoram in traditional backyard production system was $0.12 \mathrm{~kg}$, which is parallel to the value observed during the experiment. It is evident that in most of the experiments the ADG of the animals fed standard $\mathrm{CM}$ was higher as compared to those that are fed with replacement of unconventional feedstuffs. In rural areas where availability of good quality feedstuffs is limited due to various problems, the condition can influence the quality and quantity of pig feed which subsequently influences the ADG of pigs $[19,20]$. The values for ADG in animals fed chayote meal were comparable to the findings of Sotola [21] in which the ADG was $0.28 \mathrm{~kg}$. The slight variation may be due to breed differences, feed composition, environmental factors, or other physiological parameters.

\section{Digestibility of nutrients}

The digestibility coefficient of DM, CP, CF, and EE is presented in the Table-5. The values observed for DM digestibility (i.e. $78.62 \pm 1.91,79.33 \pm 0.55$, $77.25 \pm 3.89$, and $76.31 \pm 0.85$ for $\mathrm{G}_{1}, \mathrm{G}_{2}, \mathrm{G}_{3}$, and $\mathrm{G}_{4}$, respectively) were in agreement with Yadav et al. [22] who used sweet potato (Ipomoea batatas) vines for replacing the standard CM in pig and observed 64.93, 
Table-3: Weekly DM intake ( $\mathrm{g} / \mathrm{day}$ ) by pigs fed chayote meal.

\begin{tabular}{|c|c|c|c|c|c|c|c|}
\hline Week & Attributes & $\mathbf{G}_{1}$ & $\mathbf{G}_{2}$ & $\mathbf{G}_{3}$ & $\mathbf{G}_{4}$ & Mean \pm SE & $\mathbf{p}$ \\
\hline \multirow[t]{3}{*}{1} & $\begin{array}{l}\text { Concentrate } \\
\text { mixture intake }\end{array}$ & $601.06 \pm 94.32$ & 435.44 & 335.95 & 282.84 & $477.22 \pm 50.98$ & $0.19^{\mathrm{NS}}$ \\
\hline & $\begin{array}{l}\text { Cooked } \\
\text { chayote meal }\end{array}$ & - & 48.38 & 83.99 & 121.22 & & \\
\hline & Total & 601.06 & $483.82 \pm 46.55$ & $419.93 \pm 38.18$ & $404.05 \pm 24.90$ & & \\
\hline \multirow[t]{3}{*}{2} & $\begin{array}{l}\text { Concentrate } \\
\text { mixture intake }\end{array}$ & $942.93 \pm 222.50$ & 646.35 & 421.54 & 392.53 & $687.19 \pm 116.61$ & $0.17^{\mathrm{NS}}$ \\
\hline & $\begin{array}{l}\text { Cooked } \\
\text { chayote meal }\end{array}$ & - & 71.82 & 105.39 & 168.23 & & \\
\hline & Total & 942.93 & $718.17 \pm 116.40$ & $526.93 \pm 66.29$ & $560.76 \pm 61.24$ & & \\
\hline \multirow[t]{3}{*}{3} & $\begin{array}{l}\text { Concentrate } \\
\text { mixture intake }\end{array}$ & 983.42 & 842.61 & 562.99 & 629.50 & $880.67 \pm 149.45$ & $0.67^{N S}$ \\
\hline & $\begin{array}{l}\text { Cooked } \\
\text { chayote meal }\end{array}$ & - & 93.62 & 140.75 & 269.79 & & \\
\hline & Total & $983.42 \pm 222.04$ & $936.24 \pm 159.95$ & $703.74 \pm 106.55$ & $899.29 \pm 109.28$ & & \\
\hline \multirow[t]{3}{*}{4} & $\begin{array}{l}\text { Concentrate } \\
\text { mixture intake }\end{array}$ & 978.09 & 878.44 & 659.58 & 753.95 & $963.92 \pm 187.40$ & $0.92^{\mathrm{NS}}$ \\
\hline & $\begin{array}{l}\text { Cooked } \\
\text { chayote meal }\end{array}$ & - & 97.60 & 164.89 & 323.12 & & \\
\hline & Total & $978.09 \pm 236.42$ & $976.04 \pm 195.39$ & $824.47 \pm 170.02$ & $1077.07 \pm 147.78$ & & \\
\hline \multirow[t]{3}{*}{5} & $\begin{array}{l}\text { Concentrate } \\
\text { mixture intake }\end{array}$ & 1173.56 & 867.01 & 771.69 & 732.75 & $1037.08 \pm 187.83$ & $0.90^{\mathrm{NS}}$ \\
\hline & $\begin{array}{l}\text { Cooked } \\
\text { chayote meal }\end{array}$ & - & 96.33 & 192.92 & 314.04 & & \\
\hline & Total & $1173.56 \pm 248.38$ & $963.35 \pm 219.13$ & $964.61 \pm 154.77$ & $1046.79 \pm 129.04$ & & \\
\hline \multirow[t]{3}{*}{6} & $\begin{array}{l}\text { Concentrate } \\
\text { mixture intake }\end{array}$ & 1170.45 & 973.26 & 793.62 & 729.35 & $1071.45 \pm 143.91$ & $0.83^{\mathrm{NS}}$ \\
\hline & $\begin{array}{l}\text { Cooked } \\
\text { chayote meal }\end{array}$ & - & 108.14 & 198.40 & 312.58 & & \\
\hline & Total & $1170.45 \pm 213.21$ & $1081.41 \pm 153.22$ & $992.02 \pm 101.90$ & $1041.92 \pm 107.31$ & & \\
\hline \multirow[t]{3}{*}{7} & $\begin{array}{l}\text { Concentrate } \\
\text { mixture intake }\end{array}$ & 1400.79 & 1100.09 & 982.52 & 820.88 & $1255.99 \pm 172.66$ & $0.83^{\mathrm{NS}}$ \\
\hline & $\begin{array}{l}\text { Cooked } \\
\text { chayote meal }\end{array}$ & - & 122.23 & 245.63 & 351.81 & & \\
\hline & Total & $1400.79 \pm 237.44$ & $1222.32 \pm 165.11$ & $1228.16 \pm 152.85$ & $1172.69 \pm 135.27$ & & \\
\hline \multirow[t]{3}{*}{8} & $\begin{array}{l}\text { Concentrate } \\
\text { mixture intake }\end{array}$ & 1432.99 & 1190.41 & 1051.03 & 891.15 & $1335.63 \pm 183.92$ & $0.92^{\mathrm{NS}}$ \\
\hline & $\begin{array}{l}\text { Cooked } \\
\text { chayote meal }\end{array}$ & - & 132.27 & 262.76 & 381.92 & & \\
\hline & Total & $1432.99 \pm 231.34$ & $1322.67 \pm 150.46$ & $1313.79 \pm 200.46$ & $1273.07 \pm 153.42$ & & \\
\hline \multirow[t]{3}{*}{9} & $\begin{array}{l}\text { Concentrate } \\
\text { mixture intake }\end{array}$ & 1467.58 & 1230.95 & 1009.68 & 893.56 & $1343.48 \pm 90.85$ & $0.83^{N S}$ \\
\hline & $\begin{array}{l}\text { Cooked } \\
\text { chayote meal }\end{array}$ & - & 136.77 & 252.42 & 382.96 & & \\
\hline & Total & $1467.58 \pm 239.21$ & $1367.72 \pm 148.22$ & $1262.10 \pm 226.86$ & $1276.52 \pm 149.14$ & & \\
\hline \multirow[t]{3}{*}{10} & $\begin{array}{l}\text { Concentrate } \\
\text { mixture intake }\end{array}$ & 1459.79 & 1199.58 & 945.85 & 911.54 & $1319.29 \pm 183.51$ & $0.76^{\mathrm{NS}}$ \\
\hline & $\begin{array}{l}\text { Cooked } \\
\text { chayote meal }\end{array}$ & - & 133.29 & 236.46 & 390.66 & & \\
\hline & Total & $1459.79 \pm 236.80$ & $1332.86 \pm 151.74$ & $1182.31 \pm 216.94$ & $1302.20 \pm 128.64$ & & \\
\hline \multirow[t]{3}{*}{11} & $\begin{array}{l}\text { Concentrate } \\
\text { mixture intake }\end{array}$ & 1627.29 & 1386.68 & 961.40 & 866.70 & $1401.98 \pm 151.78$ & $0.18^{\mathrm{NS}}$ \\
\hline & $\begin{array}{l}\text { Cooked } \\
\text { chayote meal }\end{array}$ & - & 154.08 & 240.35 & 371.44 & & \\
\hline & Total & $1627.29 \pm 240.32$ & $1540.76 \pm 147.52$ & $1201.74 \pm 124.18$ & $1238.14 \pm 96.12$ & & \\
\hline \multirow[t]{3}{*}{12} & $\begin{array}{l}\text { Concentrate } \\
\text { mixture intake }\end{array}$ & 1580.85 & 1262.94 & 788.56 & 778.27 & $1270.41 \pm 169.83$ & $0.21^{\mathrm{NS}}$ \\
\hline & $\begin{array}{l}\text { Cooked } \\
\text { chayote meal }\end{array}$ & - & 140.33 & 197.14 & 333.54 & & \\
\hline & Total & $1580.85 \pm 253.21$ & $1403.27 \pm 142.01$ & $985.70 \pm 162.97$ & $1111.81 \pm 121.16$ & & \\
\hline \multirow[t]{3}{*}{13} & $\begin{array}{l}\text { Concentrate } \\
\text { mixture intake }\end{array}$ & 1603.80 & 1043.11 & 811.04 & 923.80 & $1274.08 \pm 139.74$ & $0.33^{\mathrm{NS}}$ \\
\hline & $\begin{array}{l}\text { Cooked } \\
\text { chayote meal }\end{array}$ & - & 115.90 & 202.76 & 395.91 & & \\
\hline & Total & $1603.80 \pm 83.20$ & $1159.01 \pm 204.60$ & $1013.80 \pm 154.59$ & $1319.71 \pm 116.56$ & & \\
\hline
\end{tabular}

DM=Dry matter, NS=Non-significant, $\mathrm{SE}=$ Standard error

77.54 , and $85.08 \%$ DM digestibility for $0 \%, 50 \%$, and $100 \%$ replacement respectively. Similar observation was also found by Manh et al. [23] who reported that the DM digestibility was 87,74 , and 74 for $2 \%, 4 \%$, 
Table-4: Growth performance of pigs of different treatment groups.

\begin{tabular}{|c|c|c|c|c|c|}
\hline Parameters & $\mathrm{G}_{1}$ & $\mathbf{G}_{\mathbf{2}}$ & $\mathbf{G}_{3}$ & $\mathbf{G}_{4}$ & $\mathbf{p}$ \\
\hline Initial body weight $(\mathrm{kg})$ & $12.61 \pm 2.34$ & $13.42 \pm 1.96$ & $12.37 \pm 1.77$ & $13.09 \pm 2.12$ & $0.98^{\mathrm{NS}}$ \\
\hline Final body weight $(\mathrm{kg})$ & $33.83 \pm 5.62$ & $34.00 \pm 4.23$ & $28.80 \pm 5.12$ & $29.83 \pm 5.34$ & $0.79^{\mathrm{NS}}$ \\
\hline Body weight gain $(\mathrm{kg})$ & $21.22 \pm 3.73$ & $20.58 \pm 2.40$ & $16.43 \pm 2.42$ & $16.73 \pm 2.00$ & $0.39^{\mathrm{NS}}$ \\
\hline Total DM intake $(\mathrm{kg})$ & $114.96 \pm 20.55$ & $101.55 \pm 13.30$ & $88.34 \pm 14.22$ & $96.07 \pm 8.69$ & $0.34^{\mathrm{NS}}$ \\
\hline FCR & $5.42 \pm 0.44$ & $4.93 \pm 0.17$ & $5.38 \pm 0.05$ & $5.74 \pm 0.53$ & $0.87^{\mathrm{NS}}$ \\
\hline ADG $(k g)$ & $0.24 \pm 0.04$ & $0.23 \pm 0.03$ & $0.18 \pm 0.02$ & $0.18 \pm 0.02$ & $0.42^{\mathrm{NS}}$ \\
\hline
\end{tabular}

$\mathrm{ADG}=$ Average daily gain, $\mathrm{FCR}=$ Feed conversion ratio, $\mathrm{DM}=$ Dry matter, NS=Non-significant

Table-5: Intake ( $\mathrm{g} / \mathrm{head} / \mathrm{day})$ and digestibility (mean $\pm \mathrm{SE}$ ) of various nutrients in the four experimental groups.

\begin{tabular}{|c|c|c|c|c|c|}
\hline Nutrients & G1 & G2 & G3 & G4 & $\mathbf{p}$ \\
\hline \multicolumn{6}{|l|}{ DM } \\
\hline Intake (g/head/day) & 1320.45 & 1538.33 & 1323.83 & 1311.16 & $0.77^{\mathrm{NS}}$ \\
\hline Digestibility (mean \pm SE) & $78.62 \pm 1.91$ & $79.33 \pm 0.55$ & $77.25 \pm 3.89$ & $76.31 \pm 0.85$ & \\
\hline \multicolumn{6}{|l|}{$\mathrm{CP}$} \\
\hline Intake (g/head/day) & 247.62 & 266.66 & 240.38 & 239.41 & $0.97^{\mathrm{NS}}$ \\
\hline Digestibility (mean \pm SE) & $79.31 \pm 3.35$ & $77.28 \pm 4.20$ & $77.89 \pm 3.94$ & $77.30 \pm 1.49$ & \\
\hline \multicolumn{6}{|l|}{$\mathrm{CF}$} \\
\hline Intake (g/head/day) & 70.52 & 75.16 & 96.91 & 96.99 & \\
\hline Digestibility (mean \pm SE) & $50.92 \pm 3.79$ & $49.99 \pm 2.54$ & $52.97 \pm 7.14$ & $60.97 \pm 1.02$ & $0.14^{\mathrm{NS}}$ \\
\hline \multicolumn{6}{|l|}{$\mathrm{EE}$} \\
\hline Intake (g/head/day) & 6.03 & 25.14 & 23.44 & 25.48 & \\
\hline Digestibility (mean $\pm S E$ ) & $51.38^{\mathrm{a}} \pm 2.56$ & $76.45^{\mathrm{b}} \pm 1.69$ & $76.03^{b} \pm 3.94$ & $75.79^{b} \pm 1.22$ & $0.00 * *$ \\
\hline
\end{tabular}

Values with similar superscripts (row-wise $a, b)$ did not differ significantly $(p>0.01)$, EE=Ether extract, $C F=C r u d e$ fiber, $\mathrm{CP}=$ Crude protein, $\mathrm{DM}=$ Dry matter, $\mathrm{SE}=$ Standard error

and $6 \%$ replacement of $\mathrm{CM}$ by water hyacinth in the ration of pigs. The values for $\mathrm{CP}$ digestibility were in agreement with Manh et al. [23] who recorded the CP digestibilities as $79.0,68.0$, and 73.0 for $2 \%, 4 \%$, and $6 \%$ levels, respectively. The results were also comparable to the observations of Madhava Rao et al. [24] in the study of inclusion of guava pomace at the level of $0 \%, 10 \%, 20 \%$, and $30 \%$ (i.e. $76.5,69.2,70.3$, and 68.9 , respectively). The decrease in the digestibility of $\mathrm{CP}$ from $\mathrm{G}_{2}$ to $\mathrm{G}_{4}$ may be due to the higher CF content of the diets. Negative influence of dietary fiber on $\mathrm{CP}$ digestibility could be attributed to the lower availability of protein added with fiber source [25]. Low digestibility of protein may also be due to protein being bound by polyphenols and fiber or physically entrapped by fiber in the chayote meal when the leaves are included [26].

The figures observed in $\mathrm{CF}$ digestibility were in agreement with the value (54.5) which was reported by Totsuka et al. [27] in growing-finishing pigs by feeding cassava as a replacement of standard CM. Fibrous components of the diet are poorly digested in the small intestine of the pig and provide substrates for microbial fermentation in the large intestine. On replacing standard $\mathrm{CM}$ with $0 \%, 3 \%, 6 \%, 9 \%$, and $12 \%$ of fermented cassava pulp, and reported the EE digestibility of was found to be $67.0 \%, 68.1 \%, 79.8 \%, 77.4 \%$, and $81.8 \%$, respectively, which was reported by Huu and Khammeng [28]. Perondi et al. [29] also reported crude fat digestibility coefficient of $83.23 \%$ when growing-finishing pigs were fed with $16 \%$ replacement of standard CM with passion fruit seed meal. These observations agree with the EE digestibility observed in the current experiment. Noblet and Perez [30] reported that the amount of digestible EE content was linearly and positively related to the dietary EE content and negatively affected by the dietary NDF content. The decreasing trend of EE digestibility in the present study may be due to the CF contents in the experimental feed.

The cost of feeding the experimental animals was calculated taking into consideration the minimal cost of the chayote fruits at wholesale price in Mizoram. The cost per kg body weight gain of experimental pigs in $\mathrm{G}_{1}, \mathrm{G}_{2}, \mathrm{G}_{3}$ and $\mathrm{G}_{4}$ was Rs. 89.15, Rs 78.77, Rs 82.64, and Rs 84.89, respectively. In Mizoram, chayote is grown mostly in the family plots or the vegetable garden. If it is available at farmer's garden, it needs not to be purchased from the market. Accordingly, the cost per kg weight gain may be further reduced and it was calculated to be Rs 89.15 , Rs 73.02, Rs 70.66, and Rs 66.02 for $\mathrm{G}_{1}, \mathrm{G}_{2}, \mathrm{G}_{3}$, and $\mathrm{G}_{4}$, respectively.

\section{Conclusion}

It can be concluded that feeding of chayote meal at different levels by replacing standard grower ration does not have any adverse effect on the growth performance and nutrient utilization of the pig. Therefore, in the pig's diet, standard grower ration may be replaced up to $40 \%$ by chayote meal safely for better economic returns by the farmers. The same experimental feed may also be tested in large exotic breeds of pigs for further scientific information.

\section{Authors' Contributions}

JL carried out the experiment and drafted the manuscript. AKS designed the experiment, guided during 
the experiment and helped in the analysis of the data. Both authors read and approved the final manuscript.

\section{Acknowledgments}

The authors express their gratitude to the Dean, College of Veterinary Sciences and Animal Husbandry, Central Agricultural University, Selesih, Aizawl and All India Coordinated Research Project (AICRP on pig) for providing the facilities and necessary funds for conducting this experiment.

\section{Competing Interests}

The authors declare that they have no competing interests.

\section{References}

1. FAO. (2012) Pig sector Kenya. FAO Animal Production and Health Livestock Country Review. No. 3. FAO, Rome.

2. Amills, M., Ramirez O., Galman-Omitogun, O. and Clop, A. (2013) Domestic pigs in Africa. Afr. Archaeol. Rev., 30: 73-82.

3. Anonymous. (2009) Mizoram: Export Potential and Prospects, Exim Bank: Research Brief, No. 50 (June).

4. Lianchawii. (2007) Natural Resource Based Income and Livelihood Improvement Initiatives in Northeastern India. In: Exploring the commercial prospects of squash as a source of livelihood in Sihphir village, Aizawl district, Mizoram, Background Paper No. 14, "Development and Growth in Northeast India: The Natural Resources, Water, and Environment Nexus. p45-51.

5. Aung, L.H., Ball, A. and Kushad, M. (1990) Developmental and nutritional aspects of chayote (Sechium edule, Cucurbitaceae). Econ. Bot., 44(2): 157-164.

6. National Research Council. (1998). Nutrient Requirement of Swine. $10^{\text {th }}$ Revised ed. National Research Council, Washington, D.C.

7. AOAC. (2000) Official Methods of Analysis. 17 $7^{\text {th }}$ ed. Vol. 2. Association of Official Analytical Chemists. Washington, DC, USA.

8. Goering, H.K. and Van Soest, P.J. (1970) Forage fibre analysis. Agricultural Handbook, 379. USDA, Washington, DC. p8-12.

9. Talapatra, S.K., Ray, S.C. and Sen, K.C. (1940) Estimation of phosphorus, chlorine, calcium, magnesium, sodium and potassium in foodstuffs. Indian J. Vet. Sci. Anim. Husband., 10: $243-246$

10. Snedecor, G.W. and Cochran, W.G. (1994) Statistical Methods. $1^{\text {st }}$ ed. East-West Press, Affiliated East-West Private Ltd., New Delhi.

11. Yoshimura, K. (1922) Nitrogenous constituents of the fruit of chayote (Sechium edule). J. Biochem., 1: 347-351.

12. Nagarajaiah, S.B. and Prakash, J. (2015) Chemical composition and bioactive potential of dehydrated peels of Benincasa hispida, Luffa acutangula, and Sechium edule. J. Herbs, Spices Med. Plants, 21: 193-202.

13. Adeniji, A.A. and Azeez, A.S. (2008) Effects of feeding growing pigs cotton seed cake with or without fish meal supplementation. J. Appl. Sci. Res., 4(10): 1253-1256.

14. Saikia, G. (2004) Effect of incorporating ajar seed kernel on the performance of crossbred pigs. Indian J. Anim. Nutr., 21(4): 254-256.

15. Keoboualapheth, C. and Mikled, C. (2003) Growth performance of indigenous pigs fed with Stylosanthes guianensis CIAT 184 as a replacement for rice bran. Livest. Res. Rural Dev., 15(9). Available from: http://www.lrrd.org/lrrd15/9/ chan159.htm. Retrieved on 08.01.2011.

16. Halimani, T.E., Ndlovu, L.R., Dzama, K., Chimonyo, M. and Miller, B.G. (2007) Growth performance of pigs fed diets containing Acacia karroo, Acacia nilotica and Colophospermum mopane leaf meals. Livest. Res. Rural Dev., 19(12): Available from: http://www.lrrd.org/lrrd19/12/ hali19187.htm. Retrieved on 09.01.2011

17. Cheverria, V.E., Belmar, R., Ly, J. and Santos-Ricalde, R.H. (2002) Effect of Leucaena leucocephala leaf meals treated with acetic acid or sodium hydroxide on apparent digestibility and nitrogen retention in pig diets. Anim. Feed Sci. Technol., 101: 151-159.

18. Kumaresan, A., Bujarbaruah, K.M., Pathak, K.A., Chhetri, B., Das, S.K., Das, A. and Ahmed, S.K. (2007) Performance of pigs reared under traditional tribal low input production system and chemical composition of non-conventional tropical plants used as pig feed. Livest. Sci., 107: 294-298

19. Mutua, F.K., Dewey, C.E., Arimi, S.M., Ogara, W.O., Githigia, S.M., Levy, M.A. and Schelling, E., (2012) A description of local pig feeding systems in village smallholder farms of Western Kenya. Trop. Anim. Health Prod., 44(6): 1157-1162.

20. Carter, N., Dewey, C., Mutua, F., de Lange, C. and Grace, D. (2013) Average daily gain of local pigs on rural and peri-urban smallholder farms in two districts of Western Kenya. Trop. Anim. Health Prod., 45(7): 1533-1538.

21. Sotola, J. (1928) Feeding pumpkins and squashes to hogs. $J$. Anim. Sci., 1: 107-109.

22. Yadav, B.P.S., Gupta, H.K. and Gupta, J.J. (1995) Sweet potato (Ipomoea batatas) on a component of swine ration. Indian J. Anim. Sci., 65(4): 455-459.

23. Manh, L.H., Dung, N.N.X., Yamasaki, S. and Takada, R. (2002) Replacement of Concentrate by Water Hyacinth (Eichroria Crassipes): Effects on Digestibility, Feed Intake and Live Weight Gain in Pig Production. Proceeding of the final workshop of JIRCAS Mekong Delta Project. Available from: http://www.ctu.edu.vn/institutes/mdi/jircas/JIRCAS/ research/workshop/Pro02/C21-\%20Replacement.pdf. Retrieved on 01-09-2011.

24. Madhava Rao, T., Ravi, A., Srinivasa Rao, D., Rama Prasad, J., Sudhakara Reddy, P. and Prabhakara Rao, Z. (2004) Effect of inclusion of guava (Psidium guajava) pomace in pig diets on growth performance, nutrient utilisation and carcass characteristics. Anim. Nutr. Feed Technol., 4: 43-52.

25. Kennelly, J.J. and Aherne, F.X. (1980) The effect of fibre in diets formulated to contain different levels of energy and protein on digestibility coefficients in swine. Can. J. Anim. Sci., 60: 717-726.

26. Phuc, B.H.N., Ogle, B. and Lindberg, J.E. (2000) Effect of replacing soybean protein with cassava leaf protein in cassava root meal based diets for growing pigs on digestibility and nitrogen retention. Anim. Feed Sci. Tech., 83: 223-235.

27. Totsuka, K., Iwai, H. and Ishiim, S.K. (1978) Study of nutritive value of cassava in rations for growing and finishing pigs. Jpn. J. Zootech. Sci., 49: 250-257.

28. Huu, H.L. and Khammeng, T. (2014) Effect of yeast fermented cassava pulp (FCP) on nutrient digestibility and nitrogen balance of post-weaning pigs. Livest. Res. Rural Dev., 26(8). Available from: http://www.irrd.org/irrd26/8/ huu26149.htm. Last accessed on 11-01-2015

29. Perondi, D., Moreira, I., Pozza, P.C., Carvalho, P.L.O., Pasquetti, T.J. and Huepa, L.M.D. (2014) Passion fruit seed meal at growing and finishing pig $(30-90 \mathrm{~kg})$ feeding. Ciên. Agrotech., 38(4): 390-400. Available from: http://www.scielo.br/scielo.php?script=sci_arttext\&pid $=\mathrm{S} 1413-70542014000400010 \& \operatorname{lng}=\mathrm{en} \& \mathrm{nrm}=$ iso. Last accessed on 19-02-2015. http://dx.doi.org/10.1590/ S1413-70542014000400010.

30. Noblet, J. and Perez, J.M. (1993) Prediction of digestibility of nutrients and energy values of pig diets from chemical analysis. J. Anim. Sci., 71: 3389-3398. 